\title{
INTERMEDIATE UNITS AND THEIR PLACE IN THE LANGUAGE SYSTEM
}

\author{
Dildorakhon Azizovna Ganieva
}

Candidate Of Philological Sciences, Associate Professor, Fergana Branch Of Tashkent State University Of Information Technologies, Uzbekistan

\section{ABSTRACT}

The article discusses functionality and intermediate units, their different interpretations in linguistics, including the views of Prague structuralisms.

KEYWORDS: - Descriptive linguistics, functionality, Prague school of linguistics, functional system, social function, expressive function, information function, poetic function, isomorphism, word groups.

\section{INTRODUCTION}

One of the most popular currents of structuralism, the Prague structuralists, who have a place in the history of world linguistics, regard the word as a product of nominative linguistic activity. In their view, internal and external events are distinguished through certain nominative activities. According to the representatives of this line, word groups are not words that are observed to occur in a certain language, but elements that are distinguished on the basis of certain oppositions. Descriptive linguistics is also characterized by a method of concrete analysis of linguistic facts. In their views, along with the lexical, grammatical features of the word, logical signs should also be taken into account.
It is well known that in world linguistics, functionality is interpreted from two points of view. The first interpretation stems from the peculiarities of the Prague linguistic school. Representatives of this school, relying on the structure of the language, pay close attention to the function of the language and its units. The term "function" is used here not in the sense of a dependency, but in the sense of a task. That is why the Prague School of Linguistics is called functional linguistics.

\section{THE MAIN FINDINGS AND RESULTS}

According to the "Theses of the Prague Linguistic Circle" language is a product of human activity and has a goal-oriented nature. Therefore, linguistic analysis should be approached from a functional point of view. In this sense, language is 
CURRENT RESEARCH JOURNAL OF PHILOLOGICAL SCIENCES 2(6): 80-83,

May 2021 DOI: https://doi.org/10.37547/philological-crjps-02-06-16

ISSN 2767-3758

(C)2021 Master Journals

\section{Crossref do) 8 Google}

Accepted25thJune, 2021 \& Published 30thJune, 2021

a system of means of expression that serves a specific purpose $[1$,$] .$

The thesis emphasizes that no phenomenon in language can be properly understood without considering the system to which the language belongs, and therefore language must be approached as a functional system. Matezius admits that the functional and structural concept of Prague linguists is based on the ideas of Baudouin de Courtenay and F. de Saussure $[2,146]$. The concept of function was developed by Prague linguists in their interpretation of language as a functional system.

While Baudouin de Courtenay distinguishes between external and internal linguistics, he strongly opposes the study of language in isolation from non-linguistic beings. He therefore pays special attention to the study of the relationship between literary language and folk dialects. Prague linguists developed these views of Baudouin. They emphasize that no language lives in a space, that it exists among the language community, that it lives to meet the communicative and expressive needs of the community. It is for this reason that Prague linguists show that speech activity performs two main functions: 1) social function (relationship between individuals); 2) expressive function (expression of excitement, influence on the speaker). The social function of speech activity, in turn, is further divided into two groups: 1) information function. In this case, the whole attention of the speaker is focused on the transmission of certain information; 2) poetic function. In this case, the main focus is on the form of transmission of information, that is, along with what to express, how to express. In the process of using language in a communicative function, extralinguistic phenomena also help it. Such phenomena include gestures, facial expressions, and speech situations. Such a language is considered by Prague linguists to be a practical language and is contrasted with a theoretical language consisting of a system devoid of a particular speech situation. Theoretical language is clear and complete, often expressed through graphic symbols and characters. In particular, the language expressed through the scientific method has such a feature.

The polyfunctional occurrence of language units is inextricably linked with their semantic complexity, syncretism $[3,8]$.

In the researches of such scientists as M.Mirtojiev, Yo.Tojiev, T.Mirzakulov, J.Eltazarov, I.Madrahimov, Z.Isakov, N.Kadirova, aimed at one or another coverage of the multifunctional nature of linguistic units in linguistics $[4 ; 5 ; 6 ; 7$; $8 ; 9 ; 10]$ provides valuable insights into the different functions of certain units in the speech process.

While Prague linguists pay special attention to function, they emphasize that there are different functions of speech activity, each of which must correspond to different functional languages. The theory of language functions and the issue of functional differentiation of literary language associated with it occupy an important place in the scientific and practical work of the representatives of the Prague School of Linguistics. Prague linguists paid special attention to the functional study of all levels of language units.

In the second interpretation, the concept of functionality is specific, defined as the performance of a particular unit in a language in addition to its function in the speech process.

The concept of functionality applies to almost all levels of language. It is well known that the occurrence of a particular phenomenon at different levels of language is called isomorphism. The term isomorphism (Latin iso similar, morpho - form) was first introduced to linguistics by E. Kurilovich, which means the 
CURRENT RESEARCH JOURNAL OF PHILOLOGICAL SCIENCES 2(6): 80-83,

May 2021 DOI: https://doi.org/10.37547/philological-crjps-02-06-16

ISSN 2767-3758

(C)2021 Master Journals

\section{Crossref do) 8 Google}

Accepted25thJune, 2021 \& Published 30thJune, 2021

similarity between the internal structure of different levels of language units [11,21]. In his view, sound complexes (e.g., joints) and semantic complexes (e.g., speech) have a deep structural parallelism, regardless of their functional relationship. There is a striking resemblance between them, which can be called isomorphism.

One of the basic principles of structural linguistic methods is the principle of unification. Accordingly, any theory should strive to unite the individual areas of the object under study, based on a single principle. In order to unite the separate spheres, it is necessary to determine the isomorphism between them, that is, the existence of a common law.

Such isomorphism is observed in the relationship between different levels of language. Therefore, the study of high-level units on the basis of research methods defined at the lower level and gaining attention in practice with accuracy, simplicity, consistency is much more convenient.

In the history of linguistics, phonological, morphemic, lexical, grammatical level units of language have been studied in many cases autonomously, without taking into account their cooperation and the presence of similar points. As a result, isomorphic cases were ignored.

The emergence of systematic linguistics, its tendency to rely on specific methods in the study of language, has led to a serious focus on the isomorphism between language levels. In particular, the representatives of the Prague School of Linguistics have successfully used the oppositional method used in phonology in the study of other levels of language.

The famous Polish linguist E. Kurilovich also notes that there is an isomorphism between the syllable and the sentence structure, so it is convenient to reveal many of the laws specific to speech on the basis of methods successfully used in the discovery of phonetic laws.

Thus, as long as the law of isomorphism applies at different levels of language, finding this law and applying the methods of verification used at the lower level and successful in the study of higher level units makes it easier to study lower level units with isomorphic units.

The convenience of applying the verification method used in lower-level units to higher-level units is that lower-level units are simpler than upper-level units. As you rise to a higher level, the signs of language units become more complex. Therefore, it is easier to identify the signs of lower level units than other levels. With this in mind, E. Kurilovich also uses the characteristic of phonetic units as a basis for comparison to check the syntactic unit.

Therefore, if we approach the phenomena of transformation and derivation that are currently confused with each other, the study of these phenomena based on the isomorphism between morphological change and syntactic change and between lexical construction and syntactic construction is called transformation and derivation of linguistic units important in illuminating similar and distinctive characters between.

The application of classification criteria and the study of the results obtained in its application have drawn the attention of linguists to the fact that these criteria cannot be bypassed even when applied together, individually or in stages. There are parts that do not fully comply with any classification basis, and at the same time do not go beyond the scope of the classification. Dialectical logic consistently distinguishes between generalities and features. Unlike features, commonalities are constantly changing and evolving. The application of dialectics to science reveals the continuity, connection, and coherence between the objects of science. Dialectical logic is built on the basis of the basic 
CURRENT RESEARCH JOURNAL OF PHILOLOGICAL SCIENCES 2(6): 80-83,

May 2021 DOI: https://doi.org/10.37547/philological-crjps-02-06-16

ISSN 2767-3758

(C)2021 Master Journals

\section{Crossref do) 8 Google}

Accepted25thJune, 2021 \& Published 30thJune, 2021

laws of dialectics. The unity and struggle of contradictions, the transition of quantitative changes to qualitative changes, deals with the laws of negation-negation. The next three laws are embodied in the intermediate third law, the special law of dialectical logic.

Through word groups, a person receives, processes, stores, and transmits information, which is why some authors prefer the term "language groups" rather than "word groups." Since the main function of word groups is verbalization of thought (verbal expression), the logical processes that form the basis of thinking are, of course, reflected in the classification and composition of word groups. Therefore, the construction principles (structure) of each individual word group, as well as the system of word groups in general, correspond to the structure of logical processes.

\section{Conclusion}

In short, from the above, we can conclude that in evaluating a particular language unit, including a particular word group, it should be approached as a separate criterion of its place in itself and in the system.

\section{REFERENCES}

1. Abstracts of the Prague Linguistic Circle.V.A.Zvegintsev, The history of linguistics in the 19th and 20th centuries in sketches and extracts Part II, Moscow: 1960

2. Matesius. Where did we come to in linguistics-VA Zvegintsev. The history of linguistics in the 19th and 20th centuries in sketches and extracts, Ch.P. Moscow: 1960,

3. Ganieva D. Syncretism and polyfunctionality in functional forms of verbs in Uzbek language: Philol. candidate of sciences ... diss. avtoref. Tashkent: 2012.

4. Mirtojiev M. Polysemy in Uzbek. Tashkent: Fan, 1975.

5. Tojiev Yo. Affixal synonymy in Uzbek language: Philol. fanlari d-ri ... diss. avtoref. Tashkent: 1992.

6. Mirzaqulov T. Problems of morpheme paradigmatics and syntagmatics of Uzbek language: Doctor of Philology ... diss. avtoref. Tashkent: 1994.

7. Eltazarov J.D. Interrelation and migration of word groups in Uzbek language: Doctor of Philology... diss. avtoref. Tashkent: 2008.

8. Madrahimov I. Versatility of the word in Uzbek language and bases of its classification: Philol. candidate of sciences ... diss. avtoref. Tashkent: 1994.

9. Qodirova N.A. Polyfunctionality in Uzbek affixes: Philol. candidate of sciences ... diss. avtoref. Tashkent: 2002.

10. Isaqov Z.S. Interrelation of word groups in Uzbek language and the place of downloads in it: Philol. candidate of sciences ... diss. avtoref. Fergana: 2005.

11. Kurilovich E. The concept of isomorphism Essays on linguistics, Moscow: 1962.

12. Oripova, G. (2019). Uzbek poetry and the world literature in the years of independence. Scientific Journal of Polonia University, 32(1), 116-120. 